TJP, 7, 2 (2015), 65-78

ISSN 0975-332X | doi:10.12726 | tjp.14.4

\title{
Concern for Future Generations: Some Perspectives
}

Sulagna Pal*

\section{Abstract}

The present research paper, entitled "Concern for Future Generations: Some Perspectives" begins with revisiting a number of ideas related with the future dressed generations from the perspective of Environmental Ethics. One of the scholarly works which I have addressed here: Work by Gregory S.Kavka who has explained the problem of future generations in the essay, "The Paradox of Future Individuals". Moreover, I have tried to highlight the view points where the scholars been addressed, fundamentally coincide and differ from each other. In the concluding part of the paper I have brought into focus 'the Buddhist theory of kamma and how the actions performed by individuals have an impact on future generations. I have shown how the actions of an individual in the present may address our concerns about the future generations. Does kamma legitimize concern for the future generations?

My work procedure has remained qualitative in nature and my remarks are both descriptive and critical of the works.

\section{Introduction and Literature Review}

No one can deny the fact that we will observe varied human reactions when the question of concern for the future generations arises. I will be analyzing a number of human attitudes towards the

* MPhil Research Scholar, Department of Philosophy, University of Delhi, India; 37sp.sulagna@gmail.com 
future generations. My exploration in this area will start with an analysis of different perspectives of philosophers in this area. The commonly observed tendency is to perform all duties towards one's own self, family, nation, and when considered from a broader perspective performing global duties at large. I will be exploring the obligations which "we" (present generation) have towards our future generations and will try to shed some light on the whole picture based on intergenerational relationship. ${ }^{1}$

Caring for one's own self of all is not unjustified. One has to take care of one's individual requirements in order to have a contended life. The problem arises when we are faced with the question of concern for our future generations. The problem originates when an individual has to make a choice between his own well being and the well being of the future generations.

It is generally believed that the minimal demands of an individual includes his need for food (to fulfill his appetite), air (to breath), water (to quench his thirst) which universally remains the same irrespective of his membership to any generation (past, present, future). The existing individuals do not need to sacrifice anything for the future generations; it is a matter of legitimate concern which the present generation needs to have for their future generations. This essay will analyze the possible reasons behind this act of concern which is expected out of the present generation.

There already exists a section of population who is of the opinion that the present generation need not take into account the well being of the future generations, since they owe them nothing. In other words a section of the presently existing population believes that they are living their lives just for themselves most importantly of all and thereby they do have the right to live it in their own terms (Some individuals even have a rather radical attitude towards future generations, to the extent that they might worsen the lives of the future generations.).

\footnotetext{
1 Avner De Shalit has dealt with the concern for the future generations justifying their claim on intergenerational relationship. In this essay I will be dealing in great detail with De Shalit's point of view which is known as the communitarian approach.
} 
There are primarily three set of behaviors observed in the present individuals towards their future generations. They are as follows:

- They (a part of the present generation) just do not care about the future generations. They are solely concerned about themselves and their individual well-being in an isolated manner.

- One part of the present generation feels that the needs of the future generations might be completely different from the presently existing ones. As a result of the difference in tastes and preferences, they believe that it is just not possible for the present generation to determine the demands of the future generations.

- The third set of present generation is concerned for the future generation but their concern is only meant for the immediate future generations. They really do not care for the well being of the distant future generations.

By the end of this short account on the concern for the future generations my aim is to reach a tenable conclusion related with my research on the future generations and our concern for them. My study is from the perspective of environmental ethics and the essay follows the line of preservation of the environment for all the generations as a whole.

Further the presently existing individuals believe that there can be no possible conflict between the demands of the present and the future generations because the presently non-existing future population cannot demand anything from the present generation owing to the fact that "they" (future generation) are presently nonexistent in the current scenario.

The question which carries a lot of weight in this field of research can be formulated in the following way:

In reality do we owe anything to our future generations?

The varied perspectives of philosophers in this area and the arguments forwarded by them in support of their respective stand 
points gives us a vision of the many folded understanding of the relationship between the existing and the coming generations.

My findings in this essay will be based on four main questions. They are as follows:

- Whether the human beings ought to have any sort of concern for the future generations (specifically distant future generations)

- If they have any sort of concern at all for the future generations, then what is the justification behind this concern?

- Do "we" (present generation) need to be concerned for the non-human future generations? If "yes" then why should we be concerned for them?

- How does belief in the doctrine of kamma impact the concern for the future generations?

\section{Section 1: Communitarian Approach}

Robert Elliot deals with the future generations and argues that the future generations can be equally holders of rights like the present generation. ${ }^{2}$ Elliot claims that the future generations are right holders and their absence in the present scenario does not justify the fact of not giving any rights to them. Elliot further believes that the rights which the future generations hold are contingent by nature. ${ }^{3}$ The contingency of the rights belonging to the future generations is based on the non-existence of the future individuals within the present scenario. All that the present generation can believe upon is the probable claim that some times ahead in the future life the future generations are going to exist.

Avner De Shalit, in his paper named, "Community and the Rights of Future Generations: A Reply to Robert Elliot", agrees with Elliot over the point that the future generations do have rights. Although

\footnotetext{
2 Robert, Elliot. 'The Rights of Future People'. Journal of Applied Philosophy, 6(2), pp. 159.

${ }^{3}$ Ibid., pp. 161. 
there is a very basic difference in both their approaches (De Shallit and Elliot's approach). ${ }^{4}$ Elliot's claim regarding the rights for the future generations is solely based on Human Rights. De Shalit disagrees with Elliot over the respective point that the rights of the future generations can be totally grounded upon human rights. According to De Shalit there has to be something more than certain man-made set of rules which can act as an intergenerational linkage. In this context he has talked about the building up of the communitarian bondage between separate, discrete generations. This simply means that the present generation needs to feel that the future generations (who are presently non-existent at the moment) are a part of the community to which "they" (present generation) themselves belong.

I am devoting an entire section of my essay to the communitarian approach to the future generations (De Shalit) because I feel that by following the communitarian approach towards the future generations the harmony between the present and the future generations is best maintained.

In this section I will be primarily dealing with the Communitarian theory of Intergenerational Justice from the perspective of Avner De Shalit. This section is based on two works by De Shalit, namely:

- Why Posterity Matters

- 'Community and the Rights of Future Generations', from the Journal of Applied Philosophy.

De Shalit opines that "we", present generations have certain obligations towards the future generations which can be primarily divided into positive and negative obligations. ${ }^{5}$ By positive obligations, he means those obligations which the present generation has towards the future generations in supplying them with all the necessary goods. By "necessary goods" he intends to include those goods which the present generation believes that the future generations will not be able to survive without. "Air" (to breath) is one such necessity for the future generations of all. While

4 Avner de, Shalit. 'Community and the Rights of Future Generations: A Reply to Robert Elliot'. Journal of Applied Philosophy, 9(1), pp. 105.

${ }^{5}$ Avner De Shalit, Why Posterity Matters, pp.13. 
the negative obligations, according to De Shalit's view point is the obligation of the present generation to do no harm to the future generations. If the present generation cannot or rather does not intend to do any welfare to the future generations none of their present acts should in any way be the cause of any misery in the lives of the future generations.

I feel it is a matter of choice for the present generation, whether they want to plant a tree or not, but the present generation should not cut down a tree planted by someone else. ${ }^{6}$ Technically speaking the present generation should not be reducing the oxygen level of the environment where the future generations are going to live their lives (sometimes in the future).

De Shalit believes that the principles justifying the intergenerational justice should fall within the scope of imagination and reasoning faculty of an individual. ${ }^{7}$ De Shalit feels that a reasonable justification is important within the communitarian approach on account of the fact that the concept of the intergenerational relationship itself is a complex matter to be borne by an individual mind.

The communitarian approach towards the intergenerational justice is based on the idea of a community, which is not limited within a particular generation. The intergenerational community stretches its boundaries not only to the immediate future generation but also the distant future generations are included within the intergenerational community. This community which is not temporally bound is known as the Transgenerational community (by De Shalit). ${ }^{8}$ The not-yet born future individuals are also considered as a member of the transgenerational community. De Shalit says that the only criterion for the membership of a transgenerational community is that the being concerned (who will be considered as a member of the trans-generational community) should be free by nature, and should have an active rational

${ }^{6}$ This example came to my mind from the ideas of positive and negative duties mentioned by Robin Attfield in his book, Environmental Ethics, pp.99.

${ }^{7}$ Avner De Shalit, Why Posterity Matters, pp.14.

8. Ibid., pp.14 
agency, which can help the individual (belonging to the present generation) in the (normative) decision making procedures. The active rational faculty of the respective individual is a "normative requirement", according to De Shalit's opinion. ${ }^{9}$ Although, De Shalit does not intend to say that the obligation of the present generation towards the future generations is based on the membership of the respective present generation to the transgenerational community.

The following quotation will shed some light on the basis of the obligation of the present generation towards the future generation, in De Shalit's view point:

"I am claiming here that the constitutive community extends over several generations and into the future, and that just as many people think of the past as part of their 'selves', they do and should regard the future as part of their 'selves'."10

De Shalit's idea of transgenerational community seems to be quite flexible by nature owing to the fact that its members are not bound by any rigid set of norms, which cannot change over time. In fact, the community members have got the full liberty of making alterations towards the norms governing them within the transgenerational community. ${ }^{11}$

By the term "community" what De Shalit understands is the concept where in people who know each other in some way or the other share the communal relation with each other respectively. ${ }^{12}$ In order to demonstrate the intergenerational relationship between distant generations, De Shalit cites counter arguments forwarded by Care and Golding for the existence of intergenerational communities, who feel that no intergenerational relationship is possible. Care opines that unless reciprocation between the two individuals belonging to the same community is possible, no amount of community bonding can develop between its members.

${ }^{9}$ Avner De Shalit, Why Posterity Matter, pp.16.

${ }^{10}$ Ibid. pp. 15-16.

${ }^{11} \mathrm{Ibid}$, Why Posterity Matters, pp. 47-49.

12Ibid, Why Posterity Matters, pp. 17. 
Golding sheds some light on another reason behind why no transgenerational community can exist; Golding feels that the individuals who are members of separate generations lack a common life on account of the lack of moral interaction. ${ }^{13}$

De Shalit on the other hand argues that the formation of a transgenerational community is a realistic venture. In support of this argument, he cites instances from human behavior which supports De Shalit's stand point.

The present generation abides by different customs and norms followed by the past generations. ${ }^{14}$ This simply shows that present generation values the relationship which they have with their past generations and intend to preserve whatever they have inherited from the past. I believe that these indications hint that the temporal distantness between generations does not alter the sense of commonality which two separate generations have in their very core. On account of this sense of commonality there seems a high chance of existence of a transgenerational community which extends over generations.

De Shalit believes that within the core of a transgenerational community lays continuity and succession. ${ }^{15}$ Since the behavioral indications observed in human beings are not sufficient grounds for justifying the existence of a transgenerational community. The main question which needs to be addressed in the course of this discussion is as follows:

What is the criterion for considering the group of individuals belonging to separate generations as part of one and the same transgenerational community?

De Shalit's analysis of the relationship between generations is wholly based on the analysis of the human psyche. De Shalit believes that the one thing which the members of the intergenerational community needs to have in common amongst themselves is the commonness of the moral principles governing

${ }^{13}$ Avner De Shalit, Why Posterity Matters, pp.18-19.

14 Ibid., Why Posterity Matters, pp. 43-44.

${ }^{15}$ Ibid., Why Posterity Matters, pp. 38-40. 
their lives. ${ }^{16} \mathrm{He}$ is in support of a pluralistic coexistence of diversified moral perspectives and he does not claim the necessity of a unanimous set of principles universally governing the lives of all particulars. ${ }^{17}$ In case of moral conflicts (what I understood by analyzing De Shalit's stand on moral pluralism) the pluralistic approach towards the intergenerational relationship is already a step ahead towards harmonizing the trangenerational community and no amount of concrete solution is necessary.

De Shalit says that the ideal portrait of a community can only be conceived when there is residence of moral similarity within it. In other words this moral similarity brings along with it a sense of oneness within the community. The base of the transgenerational community, as per conceived by De Shalit is made up of this moral similarity which can only be achieved by similarity in the natures, attitudes, values and norms of the members of the community.

According to De Shalit, it is not expected that a contemporary thinker will be emotionally attached with his future generations rather it is a bit too much of an expectation from the present generation. Whereas De Shalit believes that the origin of the sense of belongingness within the transgenerationals lays elsewhere this sense of belongingness originates from the understanding of the contemporary transgenerationals about the entire idea of the transgenerational community and its members irrespective of the time gap in the occurrence of the present and the future transgenerationals. In fact if the decisions of the transgenerationals are entirely controlled by reasons there are chances that they entirely reject their fellow members. In that way, the constitutive nature of the transgenerational community will be under threat.

The next problem which is encountered by De Shalit is related with the maintenance of the correct balance between the obligations to

16 Avner De Shalit, Why Posterity Matters, pp.27.

17 Here I have connected the ideas of John Hick supporting the existence of plurality of religions(in" Religious Pluralism", Charles Taliaferro and Paul J. Griffiths eds., Philosophy of Religion: An Anthology, Blackwell, 2003.,) with the ideas of De Shalit based on which the concept of the transgenerational community stands, in Why Posterity Matters, pp. 25-27. 
contemporaries and the obligations to the future generations respectively. What gets revealed in this way of finding the correct balance between the two sets of obligations is an important aspect of the moral similarity between the trangenerationals. Moral similarity has rationality in its very core, and the essence of a trangenerational community is its high level of rationality; thereby the rational aspect of the moral similarity has high importance in the concept of transgenerational community. ${ }^{18}$

\section{Section 2: Future Generations and Early Buddhism}

The Buddhist school of thought divides the kamma or volitional actions performed by an individual into the following three categories, namely:

- Morally good actions (kusala kamma).

- Morally evil actions (akusala kamma).

- Morally neutral actions (avyakta kamma). ${ }^{19}$

Moreover, the consequence of the kamma performed by an individual does not remain limited within the present life of the performer. The Buddhist Kamma Theory relates the presently performed intentional acts of an individual with the condition of the respective being in his future life. The nature of the kamma performed by an individual is the cause behind the condition of an individual in his next life. The Culakammavibhanga Sutta, from the Majjhima Nikaya, also demonstrates the reason behind the differences between individuals belonging to the same generation itself. The reason lies nowhere else other than the negative deeds (akusala kamma) performed by an individual in his previous birth. Hence if we look around us we will be able to find out individuals who are high born, low born; ugly, beautiful etc. and relate these seen differences to the Buddhist theory of kamma respectively.

If excessive amount of negative energy is produced by the intentional acts of an individual in his present life, then in his next birth, on account of his past misdeeds, he will be reborn in a realm,

18 Avner De Shalit, Why Posterity Matters, pp. 28-29.

${ }^{19}$ K.N Jayatilleka, Survival and Karma in Buddhist Perspective, pp.3. 
which is situated below the human realm and henceforth will be subject to miserable living conditions (In the Buddhist school of thought rebirth of an individual being is accepted.). I have described the realms below, following the Buddhist interpretation of the theory of kamma.

There are 6 realms described in the Buddhist Theory of kamma.20 They are as follows: God, Human, Hungry ghost, Titan, Animal, Hell beings

An action performed by an individual produces some energy (negative or positive). This energy created by the kamma of an individual does not get used up unless it shows its impact on the being in his next life.

So what we can infer from the above discussion related with theory of kamma from the Buddhist perspective: The one belonging to the present generation will concern for the future generations if and only if he is concerned about himself. In other words the individual who does not want to lead a miserable life in his next birth (which will be located below the human realm) has to stop himself from performing akusala kamma (morally evil actions) in his present life.

The future person gets linked to me by means of the dispositional habits created by me in my present life. The Future life of mine gets affected by the energy dissipated by the presently performed intentional acts of mine. The Theory of Conservation of Energy states that energy can neither be created nor be destroyed can be related with the Buddhist interpretation of the theory of kamma. The energy which my presently performed volitional acts create cannot be destroyed. This energy created by me, in my present life can be both positive and negative and henceforth the effectuation of this created energy in the future life is solely dependent on my present activities. Therefore it is me who is going to decide my future location in a respective realm.

20 James P. McDermott, "Karma and Rebirth in Early Buddhism", Karma and Rebirth in Classical Indian Tradition. These five realms are listed in the Digha Nikaya (D) 3.254 etc. and the sixth category is mentioned in (D 3.264). 
De Shalit's communitarian approach, reminds me of the Theory of kamma. I believe that the obligations which the contemporary generations have towards the future generations can be well interpreted by the working of the kammic principles respectively. In fact, based on my understanding of De Shalit's arguments, forwarded by him within the section on Transgenerational communities, what I felt is that he himself (implicitly) believes that the actions of a presently existing individual is deeply related with his past and present lives. (Although, De Shalit might not have intentionally related his arguments with the Buddhist doctrine of kamma.).

I will come to a closure of this short accounting on the concern for the future generations by reminding my readers an essential part of our lives: The present generation cannot afford to forget that the resources which the present generation is utilizing at the present moment does not belong entirely to them. Moreover I strongly feel that doctrine of kamma (viewed from the early Buddhist perspective) can act as a strong ground to justify the concern for the future generations.

\section{References}

Attfield, Robin. Environmental Ethics. Polity Press, Cambridge, U.K, 2003.

Barry, Brian. 'Sustainability and Intergenerational Justice'. Theoria, 45(89), June, 43-64.1997.

Barry, Brian. 'Circumstances of Justice and Future Generations'. Obligations to Future Generations, Cambridge: White Horse Press, 204-48, 1996.

Beckermen, Wilfred. 'Sustainable Development and our Obligations to Future Generations', in Andrew Dobson (ed.). Fairness and Futurity: Essays on Environmental Sustainability and Social Justice, Chapter 3, Oxford: Oxford University Press, 71-92, 287-91, 1999.

Burton, David. 'Buddhism' ,The Routledge Companion to the Philosophy of Religion, London: Routledge, in Chad Meister and Paul Copan (eds), 16-27, 2007. 
Doniger, Wendy O'Flaherty. Karma and Rebirth in Classical Indian Tradition, Motilal Banarasidas,1999.

Elliot, Robert. 'The Rights of Future People'. Journal of Applied Philosophy, 6(2), 159-169,1989.

Hick, John, "Religious Pluralism", Charles Taliaferro and Paul J. Griffiths eds., Philosophy of Religion: An Anthology, Blackwell, 2003.

Jayatilleka K.N. Survival and Karma in Buddhist Perspective, Buddhist Public Society, Online Edition, 2008, accessed on 10th April 2012.

Kavka, Gregory.S. 'The Paradox of Future Individuals', Philosophy and Public Affairs, 11(2), Spring, 93-112.1982.

Krishan Yuvraj,. The Doctrine of Karma In Origin and Development in the Brahmanical, Buddhist and Jaina traditions, Motilal Banarasidas, 1997.

Masih, Y, A Critical History of Western Philosophy, Motilal Banarasidas, pp. 388, 2010.

Nickel, James. W and Viola, Eduardo. 'Integrating Environmentalism and Human Rights'. Environmental Ethics, edited by Andrew Light and Holmes Rolston III, Blackwell Publishers,472-477,2003.

O'Neill, John. 'Future Generations: Present Harms'. Philosophy, 68(264), April, 35-51.1993.

Parfit, Derek. 'Future Generations: Further Problems'. Philosophy and Public Affairs, 11(2), Spring, 113-72.1982.

Radhakrishnan, Indian Philosophy Volumes 1 and 2. London: George Allen and Unwin Ltd. New York: Humanities Press INC. 1977 (reprint). 33

Sayadaw Pa Auk Tawya, The Workings of Kamma, Helicon Publishing and Penguin Books Ltd:1996.

Shalit, Avner de. 'Community and the Rights of Future Generations: A Reply to Robert Elliot'. Journal of Applied Philosophy, 9(1), 105-15.1992.

Shalit, Avner de. Why Posterity Matters Environmental Policies and Future Generations, Routledge, London and U.S.A and Canada.1995. 
Smith, Patrick Nowell. "Morality Religious and Secular", The Rationalist Annual, London: Pemberton Publishing Co. Ltd., 1961.

Sharma, I.C and Daugert, Stanley M.E, Six Ethical Ways of Knowing, London: George Allen and Unwin U.K, 1965. 